\title{
Endo and exoglucanases produced by Penicillium citrinum isolated from Amazon
}

\author{
Pamella Suely Santa Rosa Pimentel ${ }^{1 *}$, Anita Lima de Souza ${ }^{2}$, Ana Tana Rosas Nascimento ${ }^{1}$, \\ Edmar Vaz de Andrade 1 , Spartaco Astolfi-Filho ${ }^{3}$, Carlos Gustavo Nunes-Silva ${ }^{3}$ \\ From 5th Congress of the Brazilian Biotechnology Society (SBBIOTEC) \\ Florianópolis, Brazil. 10-14 November 2013
}

\section{Background}

Cellulolytic enzymes (glucohidrolases - EC 3.2.1.-) are biocatalizators highly specific. They act in synergy to hydrolyze $\beta-1,4$ bonds between monosaccharide units of $D$-glucose in the cellulose chain releasing its constituents. Cellulases are categorized according to the place they act in the cellulosic fiber. Endoglucanases start hydrolysis, exoglucanases act in the reduced terminal produced by endoglucanases followed by $\beta$-glycosidase which act in the product of exoglucanases catalysis releasing glucose monomers.

Fungi are considered the best cellulolytic enzyme producers due to its natural cellulases that complete saccharification of lignocellulose. Species of Penicillium have been reported as excellent producers of cellulolytic enzymes when compared to commercial species and strains [1]. Aiming to contribute to biocatalytic processes and obtention of new sources for cellulolytic enzyme, this work has as objective the production of endoglucanases and exoglucanases from Penicillium citrinum isolated from an agro industrial residue in Amazon.

\section{Methods}

Sample was isolated from sugar-cane bagasse in agro industry of Amazonas, by the municipality of Presidente Figueiredo-AM-Brasil, $110 \mathrm{~km}$ from Manaus. Molecular identification was made by ITS-18S gene amplification, followed sequence analysis of using software Bioedit Sequence Alignment Editor ${ }^{\circledR}$ and BLAST from NCBI (BLASTn). For the production of cellulolytic enzymes fungi was cultivated during $192 \mathrm{~h}$ in submerse fermentation, having carboxymethylcellulose $(\mathrm{CMC})$ as carbon source [2]. Enzymatic assays were done in triplicate [3,4]

'Federal University of Amazonas, Manaus, AM, Brazil

Full list of author information is available at the end of the article incubating the culture supernatant in presence of substrates CMC for endoglucanases and avicel (microcrystalline cellulose) for exoglucanases. Total secreted protein was quantified by using BCA kit (Thermo Scientific ${ }^{\circledR}$ ). Enzymatic activity was calculated according to international unities- IU ( $1 \mathrm{IU}$ is equal to $1 \mu \mathrm{mol}$ of released product) and, the values were presented in $U / m g$. As experimental control all the assays were also done with a commercial strain of Trichoderma reesei (QM 9414).

\section{Results and conclusions}

Fungi specie was confirmed as Penicillium citrinum, having $100 \%$ identity and similarity in BLASTn alignment. Regarding to endoglucanase production was observed two peaks, one with $72 \mathrm{~h}$ and with $144 \mathrm{~h}$ of cultivation, and enzyme activity of $9.67 \mathrm{U} / \mathrm{mg}$ and $8.32 \mathrm{U} / \mathrm{mg}$, respectively. This results were comparable to those obtained for T. reesei (QM 9414), which was observed activity equal to 12.50 and $14.37 \mathrm{U} / \mathrm{mg}$ respectively. Exoglucanase activity was higher in $P$. citrinum $(0.64 \mathrm{U} / \mathrm{mg}, 96 \mathrm{~h})$ than that in $T$. reesei $(0.43 \mathrm{U} / \mathrm{mg}, 168 \mathrm{~h})$, as indicated by Singh and co-authors [5]. Production profile of endoglucanases and exoglucanases of $P$. citrinum showed to be highly synergic since the exo activity increases gradually and its peak is related to endo activity decay. Therefore $P$. citrinum presents a good potential as alternative to celulolytic enzyme production.

\section{Acknowledgements}

This study was funded by CNPq, CAPES, FAPEAM and Biotech Amazonia LTDA-ME

\section{Authors' details}

${ }^{1}$ Federal University of Amazonas, Manaus, AM, Brazil. ${ }^{2}$ Biotech Amazonia LTDA-ME, Manaus, AM, Brazil. ${ }^{3}$ Federal University of Amazonas, Biotech Amazonia LTDA-ME, Manaus, AM, Brazil. 


\section{References}

1. Martins L F, Kolling D, Camassola M, Dillon AJP, Ramos LP: Comparison of Penicillium echinulatum and Trichoderma reesei cellulases in relation to their activity against various cellulosic substrates. Bioresource Technology 2008, 99:1417-1424.

2. Szijártó N, Szengyel Z, Lidén G, Réczey K: Dynamics of Cellulase Production by Glucose Grown Cultures of Trichoderma reesei Rut-C30 as a Response to Addition of Cellulose. Applied Biochemistry and Biotechnology 2004, 113(116):115-124.

3. Ghose TK: Measurement of Cellulase Activities. Pure \& Applicate Chemistry 1987, 59(2):257-268.

4. Zhang YHP, Hong J, Ye X: Cellulase Assays. Biofuels: Methods and Protocols, Methods in Molecular Biology 2009, 581:213-231.

5. Singh R, Varma AJ, Laxman RS, Rao M: Hydrolysis of cellulose derived from steam exploded bagasse by Penicillium cellulases: Comparison with commercial cellulose. Bioresource Technology 2009, 100:6679-6681.

doi:10.1186/1753-6561-8-S4-P179

Cite this article as: Rosa Pimentel et al:: Endo and exoglucanases produced by Penicillium citrinum isolated from Amazon. BMC Proceedings 2014 8(Suppl 4):P179

\section{Submit your next manuscript to BioMed Central} and take full advantage of:

- Convenient online submission

- Thorough peer review

- No space constraints or color figure charges

- Immediate publication on acceptance

- Inclusion in PubMed, CAS, Scopus and Google Scholar

- Research which is freely available for redistribution

Submit your manuscript at www.biomedcentral.com/submit 